\title{
PURIFICATION AND CHARACTERIZATION OF GLUTATHIONE S-TRANSFERASE FROM THE HUMAN HEPATOMA DERIVED PLC/PRF/5 CELL LINE
}

\author{
Paul J. DierickX \\ Instituut voor Hygiëne en Epidemiologie, Wytsmanstraat 14, B-1050 Brussel, Belgium
}

\begin{abstract}
PLC/PRF/5 cells, an established cell line derived from a human hepatoma, were cultured to large numbers in a cell factory for the isolation of glutathione S-transferase. This enzyme interacts in many toxicological important reactions. The enzyme was enriched by affinity chromatography, and further purified by cation exchange chromatography and anionic chromatofocusing. The enzyme activity was always recovered in one peak only. The sole transferase was identified as human glutathione S-transferase $\pi$ by its pl ( $\mathrm{pH} 4.4$ on chromatofocusing), its kinetic properties, the effect of specific inhibitors, and by its subunit structure, as determined by electrophoresis (one band at $M_{\mathrm{r}} 26,000$ ). The results are discussed in the view that glutathione S-transferase $\pi$ is considered as a tumor marker: Since PLC/ PRF/ 5 cells contain exclusively the glutathione S-transferase $\pi$ isoenzyme, these cells cannot be used as an alternative model for intact human liver. However, they are a promising source for the study of specific glutathione S-transferase $\pi$-dependent metabolic processes, for example in relation to cancer.
\end{abstract}

Reduced glutathione (GSH) plays an important role in the detoxication of potentially toxic compounds. Its most widely known biological role is the conjugation with xenobiotics, including carcinogens, mutagens, toxic or pharmacologically active compounds, and their metabolites (3). This conjugation is catalyzed by glutathione S-transferase (GST, EC 2.5.1.18), of which multiple isoenzymes are described, as recently reviewed (14). GST is also capable of direct binding of toxic compounds, another important detoxication pathway (19). Moreover, GST has peroxidase activity for organic hydroperoxides and, therefore, the potential to detoxify lipid and DNA hydroperoxides arising from radical damage in the presence of oxygen (22). GST isoenzymes may also have diagnostic value as tumor markers (16).
The liver is the principal organ involved in the biotransformation and detoxification of xenobiotics. It is also the first organ after the gastrointestinal tract a drug passes after oral intake. Therefore, knowledge of hepatic metabolic pathways of xenobiotics is of major importance. Attempts to establish permanent cell lines of hepatocytic origin were unsuccesful so far, because typical biochemical functions are lost. GST activity, however, is found in any cell line investigated, albeit in highly different degrees $(2,17)$, and I previously reported that Hep G2 cells contain GST activity (4). Afterwards a four times higher GST activity was observed in $\mathrm{PLC} / \mathrm{PRF} / 5$ cells, an established cell line, derived from a human hepatoma (13). An interesting aspect of these cells is that they have the biosynthetic capabilities of normal liver parenchymal cells (10). 
They synthesize and secrete 11 of the major human plasma proteins (10) and produce the hepatitis B surface antigen $(10,13)$. Moreover they metabolize 3,4-benzpyrene and aldrin, proving that they contain at least two different forms of $\mathrm{P}_{450}$ cytochromes (12). Since liver GST plays a central role in different detoxication pathways $(3,19,22)$ and since cultured $\mathrm{PLC} / \mathrm{PRF} / 5$ cells have many hepatocyte characteristics, I investigated the GST in this hepatoma cell line.

\section{MATERIALS AND METHODS}

The PLC/PRF/s cells were provided by $\mathrm{Dr}$ Y.-J. Schneider, UCL, Louvain-la-Neuve, Belgium. Cell culture flasks were purchased from Nunc, and cell culture products from Gibco. GSH and bromosulfophtalein were obtained from Janssen Chimica (Beerse, Belgium), bovine serum albumin from Boehringer, chemicals for SDS-polyacrylamide gel electrophoresis from Bio-Rad, carboxymethyl cellulose (CM52) from Whatman, and epoxy-activated Sepharose 6B, PD-10 columns containing $10 \mathrm{ml}$ Sephadex G-25 Medium, Polybuffer exchanger 94, Polybuffer 74, and the low molecular weight protein calibration kit from Pharmacia. Amicon furnished the YM-10 ultrafiltration membranes. Hematin came from Sigma, and all other chemicals from Merck, including triphenyltin chloride and the GST substrate 1-chloro-2,4-dinitrobenzene (CDNB).

The cells were maintained in Dulbecco's modified Eagle's medium (DMEM) supplemented with $10 \%$ fetal calf serum, 100 units/ $\mathrm{ml}$ penicillin, and $100 \mu \mathrm{m} / \mathrm{ml}$ streptomycin (complete medium). They were incubated at $37^{\circ} \mathrm{C}$ in a $7 \% \mathrm{CO}_{2}$ atmosphere.

Specific GST activities were determined on cells cultured in tissue flasks with a growth surface of $175 \mathrm{~cm}^{2}$. The same results were obtained when the cells were either loosened by trypinisation or by scraping.

For the purification of GST the PLC/PRF/ 5 cells were cultured in a cell factory, consisting of 10 separate chambers, with a total culture surface of $6,000 \mathrm{~cm}^{2}$. The cells were harvested when nearly reaching confluency. They were washed with $500 \mathrm{ml}$ Hanks' balanced salt solution, trypsinised with $125 \mathrm{ml}$ of $0.25 \%$ trypsin, suspended in $400 \mathrm{ml}$ of com- plete medium, and centrifuged at $1,000 \mathrm{~g}$ for $10 \mathrm{~min}$. Further manipulations were carried out at $0-4^{\circ} \mathrm{C}$. The cells were homogenized in $10 \mathrm{ml}$ of $22 \mathrm{mM}$ sodium phosphate buffer, $\mathrm{pH}$ 7.0 , containing $0.25 \mathrm{M}$ sucrose and $1 \mathrm{mM}$ EDTA $\cdot \mathrm{Na}_{4}$, with 10 up-and-down strokes in a motor driven Potter-Elvehjem homogenizer (1,500 rpm), equipped with a Teflon pestle. A fat-free supernatant obtained after ultracentrifugation $(1 \mathrm{~h}, 100,000 \mathrm{~g})$ was applied to a GSH affinity column $(1.6 \times 9 \mathrm{~cm})$, packed with epoxy-activated Sepharose 6B that had been reacted with GSH as described (18). The column was eluted with $22 \mathrm{mM}$ sodium phosphate buffer, pH 7.0 , containing $1 \mathrm{mM}$ EDTA $\cdot \mathrm{Na}_{4}$, until no further protein was detected by monitoring the absorbance at $290 \mathrm{~nm}$. GST was then eluted with $15 \mathrm{mM}$ GSH in $50 \mathrm{mM}$ Tris-HCl buffer, pH 9.6 (23). The fractions with GST activity were pooled, concentrated to $2.5 \mathrm{ml}$ by ultrafiltration on a YM-10 membrane, equilibrated with $5 \mathrm{mM}$ sodium phosphate buffer, pH 7.0, containing $1 \mathrm{mM}$ EDTA $\cdot \mathrm{Na}_{4}$, on a PD-10 column, and applied to a carboxymethyl cellulose column $(1.6 \times 9.5 \mathrm{~cm})$, equilibrated with the same buffer. The anionic proteins are not adsorbed when eluted with this buffer. The cationic proteins were later eluted with $100 \mathrm{mM}$ sodium phosphate buffer, $\mathrm{pH} 7.0$, containing $1 \mathrm{mM}$ EDTA $\cdot \mathrm{Na}_{4}$. No further GST was eluted with $1 \mathrm{M} \mathrm{NaCl}$. The fractions with GST activity were pooled, concentrated again to $2.5 \mathrm{ml}$ by ultrafiltration on a YM-10 membrane, equilibrated with $25 \mathrm{mM}$ imidazole- $\mathrm{HCl}$ buffer, $\mathrm{pH}$ 7.4 , on a PD-10 column, and applied to a Polybuffer exchanger 94 column $(1.0 \times 34 \mathrm{~cm})$, equilibrated with $25 \mathrm{mM}$ imidazole- $\mathrm{HCl}$ buffer, pH 7.4. Elution was carried out with Polybuffer 74 , diluted $1 / 16$, and adjusted to $\mathrm{pH} 4.0$ with $\mathrm{HCl}$. The $\mathrm{pH}$ was monitored with a Pharmacia $\mathrm{pH}$ monitor.

SDS-polyacrylamide slab gel electrophoresis was carried out on $12.5 \%$ polyacrylamide gels as described (11).

The GST activity was measured as described (6) using CDNB as substrate. Specific activity is expressed in units of enzyme activity/mg protein, as measured by the Bradford method (1) with bovine serum albumin as standard. Kinetic properties were examined measuring the initial velocities of GST at GSH and CDNB concentrations varying from 


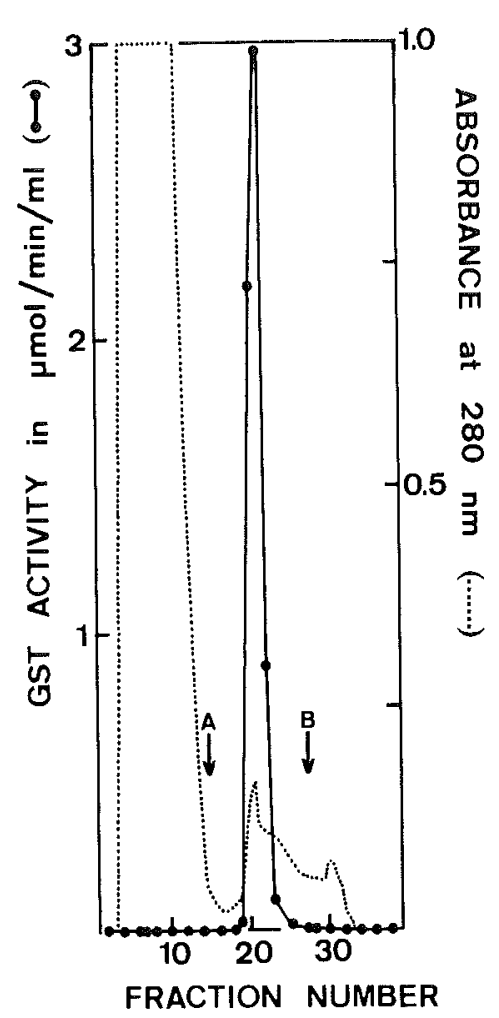

Fig. 1 Elution of PLC/PRF/5 GST activity from a GSH affinity column. The column was first rinsed with $22 \mathrm{mM}$ sodium phosphate buffer, $\mathrm{pH} 7.0$, containing $1 \mathrm{mM}$ EDTA. $\mathrm{Na}_{4}$, and then eluted with $15 \mathrm{mM}$ GSH in $50 \mathrm{mM}$ Tris- $\mathrm{HCl}$, pH 9.6 (arrow A). Thereafter the column was eluted with $3 \mathrm{M} \mathrm{NaCl}$ (arrow B). Fractions of $3 \mathrm{ml}$ were collected.

0.25 to $1 \mathrm{mM}$. They were analyzed by Lineweaver-Burk plots. The GST inhibitors were tested as described (21).

\section{RESULTS}

The specific GST activity in PLC/PRF/5 cells is $442 \pm 41 \mathrm{nmol} / \mathrm{min} / \mathrm{mg}$ protein. A sufficiently large quantity of cells was obtained after cultivation in a cell factory with a total growth surface of $6,000 \mathrm{~cm}^{2}$. The $100,000 \mathrm{~g}$ supernatant of the cell extract was first enriched by GSH affinity chromatography (Fig, 1). GST was quantitatively bound to the matrix, since no trace of GST activity was observed in the flow-through fractions, and it was quantitatively desorbed with $15 \mathrm{mM}$ $\mathrm{GSH}$, since further elution with $3 \mathrm{M} \mathrm{NaCl}$ did

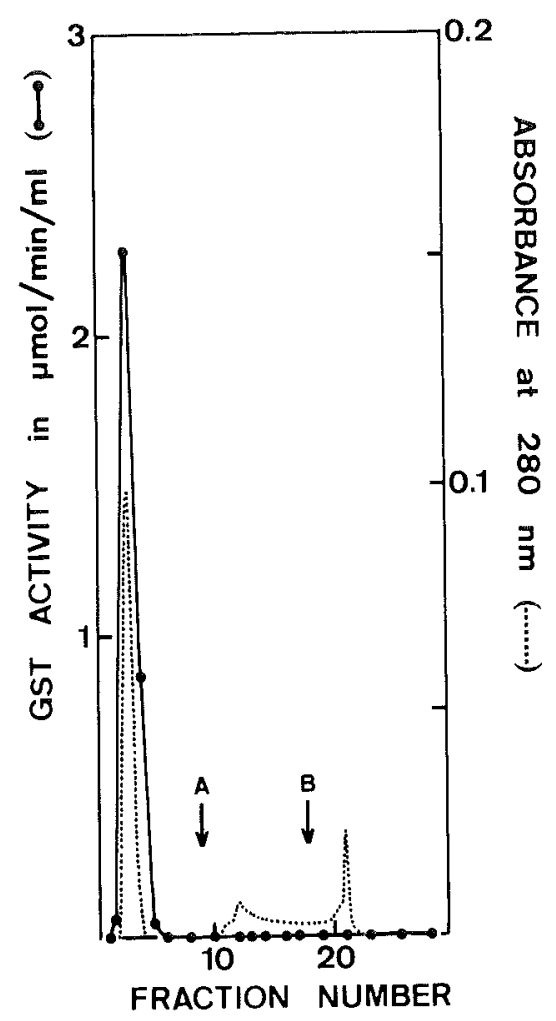

Fig. 2 Chromatography of the by affınity chromatography enriched GST on a carboxymethyl cellulose column. The column was consecutively eluted with $5 \mathrm{mM}$ and next with $100 \mathrm{mM}$ (arrow A) sodium phosphate buffer, pH 7.0 , containing $1 \mathrm{mM}$ EDTA $\cdot \mathrm{Na}_{4}$, and $1 \mathrm{M} \mathrm{NaCl}$ (arrow B). Fractions of $4.5 \mathrm{ml}$ were collected.

not further elute any GST activity.

The GST fractions which were eluted with $15 \mathrm{mM}$ GSH from the affinity matrix were applied on a carboxymethyl cellulose column (Fig. 2). Anionic GST passed quantitatively through the column with the low ion-strength equilibration buffer of $5 \mathrm{mM}$ sodium phosphate, $\mathrm{pH} 7.0$, containing $1 \mathrm{mM}$ EDTA $\cdot \mathrm{Na}_{4}$. None of both higher ion-strength elution solutions did further desorb any GST activity. This means that the PLC/PRF/5 GST is exclusively composed of anionic GST. Part $(10 \%)$ of this purified GST was used for kinetic and inhibition experiments. The other part was further purified by anionic chromatofocusing (Fig. 3). Again, only one single GST peak was observed, eluting at $\mathrm{pH}$ 4.4. The SDS-polyacrylamide slat gel electrophoreto- 


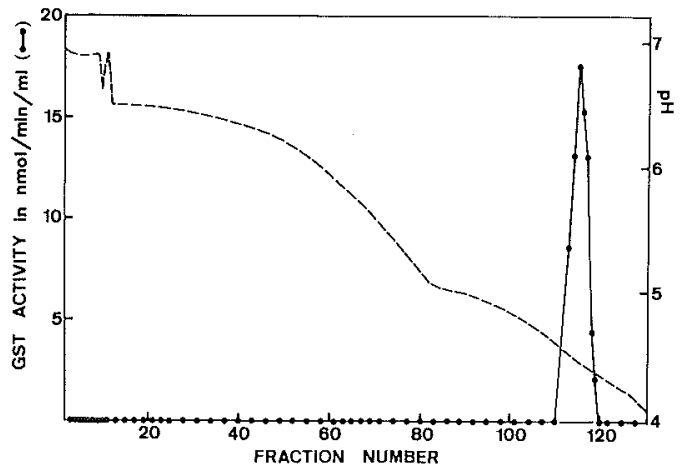

Fig. 3 Anionic chromatofocusing of PLC/PRF/5 GST on a Polybuffer exchanger 94 column. The column, equilibrated with $25 \mathrm{mM}$ imidazole- $\mathrm{HCl}$, $\mathrm{pH} 7.4$, was developed with Polybuffer 74, diluted $1 / 16$, and adjusted to $\mathrm{pH} 4.0$ with $\mathrm{HCl}$. Fractions of $3 \mathrm{ml}$ were collected.

gram of PLC/PRF/5 GST is shown in Fig. 4. The Coomassie blue stained gel showed only one band with a $M_{\mathrm{r}}$ of 26,000 . This indicates that PLC/PRF/5 GST is a homodimer, since GST enzymes have a dimeric structure (14).

Some kinetic parameters of the PLC/PRF/ 5 GST $^{\prime}$ are summarized in Table. 1. The apparently pure GST has a very high specific activity. Linear Lineweaver-Burk plots $(r>0.99)$ were always observed in the kinetic experiments. The PLC/PRF/5 GST was further characterized by measuring the influence of a set of discriminating GST inhibitors (Table 2). Gossypol acetic acid had the least inhibiting effect, while hematin was the strongest inhibitor.

\section{DISCUSSION}

Our results show that PLC/PRF/5 cells have only one GST isoenzyme, since the GST activity was always found in a single peak, without any trace of activity in other fractions. This situation sharply contrasts with different biological tissues and cells, where several isoenzymes are found (14). At least 15 different GST isoenzymes were demonstrated in human liver, although not all forms were detectable in all liver sample (24). The multiplicity of GST isoenzymes is assumed to result from the need to conjugate numerous types of substances differing in the nature of their electrophilic centre and their molecular struc-

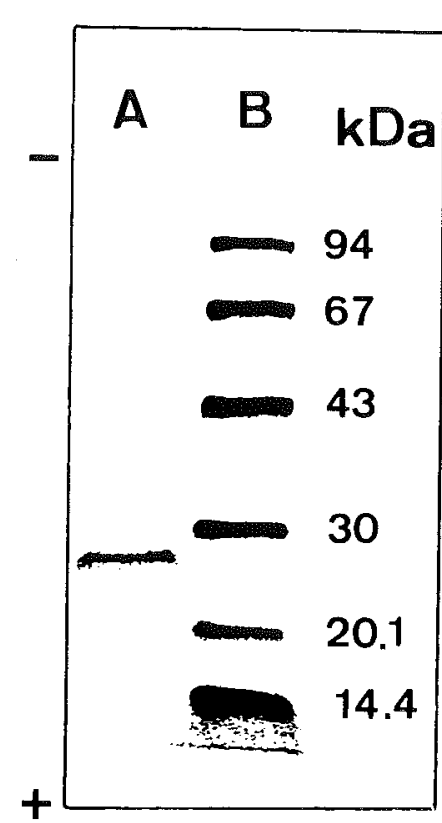

Fig. 4 SDS-polyacrylamide electrophoretic gel showing one subunit for PLC/PRF/5 GST. Lane A: PLC/PRF/5 GST, lane B: standard proteins

ture (9). Therefore, the investigated cell line can by no means be considered as a valuable alternative model for the study of GST-dependent interactions in the human liver, although the cells have many other hepatocyte characteristics $(10,12,13)$.

Another important difference is that the majority of the human liver GSTs are cationic forms (24), whereas the PLC/PRF/5 GST is only found in one single anionic peak, with $\mathrm{pl}$ 4.4 (Fig. 3). A human anionic GST was first isolated from erythrocytes (15), and later on from many different tissues as placenta, lung, kidney, and lens. These proteins correspond to the same enzyme and are now designated as GST $\pi$ (14), which shows very close homology with GST 7-7 from the rat (8).

The GST isolated from PLC/PRF/5 cells can be identified as GST $\pi$ on the basis of the following criteria. The pl (Fig. 3) and the $\mathrm{K}_{\mathrm{m}}$ values (Table 1) correspond with those of GST $\pi(5)$. The homodimeric structure with two identical subunits of $M_{\mathrm{r}} 26,000$ (Fig. 4) agrees with that of GST $\pi(20)$, although other authors reported a slightly lower $M_{\mathrm{r}}(5,14)$. Finally, the $\mathrm{IC}_{50}$ values from Table 2 corre- 
Table 1 Some Kinetic Parameters of PLC/PRF/5 Glutathione STransferase

Specific activity

Apparent $\mathrm{K}_{\mathrm{m}}$ towards $\mathrm{CDNB}^{b}$

Apparent $\mathrm{V}_{\max }$ towards CDNB ${ }^{\mathrm{b}}$

Apparent $\mathrm{K}_{\mathrm{n} 1}$ towards $\mathrm{GSH}^{\mathrm{c}}$

Apparent $V_{\max }$ towards $G S^{c}$
$114 \mu \mathrm{mol} / \mathrm{min} / \mathrm{mg}$ protein

$2.19 \mathrm{mM}$

$118.5 \mu \mathrm{mol} / \mathrm{min} / \mathrm{mg}$ protein

$0.17 \mathrm{mM}$

$66.6 \mu \mathrm{mol} / \mathrm{min} / \mathrm{mg}$ protein

${ }^{a}$ Measured with both CDNB and GSH at $1 \mathrm{mM}$. ${ }^{\mathrm{b}}$ Measured at a fixed concentration of $1 \mathrm{mM}$ GSH. "Measured at a fixed concentration of $1 \mathrm{mM}$ CDNB

Table 2 Inhibition Parameters for PLC/PRF/5 Glutathione S-Transferase

\begin{tabular}{lc}
\hline \multicolumn{1}{c}{ Inhibitors } & $\mathrm{IC}_{50}(\mu \mathrm{M})$ \\
\hline Gossypol acetic acid & 460 \\
Triphenyltin chloride & 13 \\
Bromosulfophtalein & 49 \\
Hematin & 5 \\
S-Hexylglutathione & 19 \\
\hline
\end{tabular}

The $\mathrm{IC}_{50}$ is the concentration of inhibitor giving $50 \%$ inhibition of enzyme activity, measured with GSH and CDNB at $1 \mathrm{mM}$.

spond very well to those of GST $\pi$ (21). They exclude the possibility that another previously described GST isoenzyme, other than GST $\pi$, was isolated from PLC/PRF/5 cells. No trace of other GST activity containing peaks was detected during the different purification steps (Figs. 1-3), although usually at least a small part of GST activity freely passes the affinity matrix (24). Therefore it is concluded that the GST in the investigated hepatoma derived PLC/PRF/5 cell line is entirely composed of GST $\pi$. Although GST $\pi$ is reported as the major GST isoenzyme in different cell lines (17), no established cell line has been described, to the best of my knowledge, in which GST $\pi$ is the sole GST isoenzyme.

GST $\pi$ (and its rat homologue GST 7-7) are now generally considered as a tumor marker in a variety of tissues. GST $\pi$ content is higher in human hepatic tumors than in surrounding non-tumor tissue, in normal liver, or in liver tissue of patients with liver diseases other than hepatic tumors (20). It is also the major isoenzyme in a variety of human tumors from different tissues (17). GST 7-7 has become established as one of the best markers for early detection of putative preneoplastic and neo- plastic cells in rat chemical hepatocarcinogenesis (16). It was introduced as a marker for analysis of carcinogenic processes and for screening of carcinogens and carcinogen modifiers $(7,16)$.

In conclusion, the human hepatoma derived PLC/PRF/5 cells cannot be considered as an alternative model for intact human liver. However, being derived from an hepatoma, they contain exclusively GST $\pi$, specific for tumors. Therefore they are a promising source for the study of specific GST $\pi$-dependent metabolic processes, for example in relation to cancer.

I thank Mrs J. Erna for her excellent technical assistance, and Dr Y. J. Schneider for providing the PLC/PRF/5 cell line.

Received for publication 5 June 1989; and in revised form 26 June 1989

\section{REFERENCES}

1. BradFord M. M. (1976) A rapid and sensitive method for the quantitation of microgram quantities of protein utilizing the principle of protein-dye binding. Anal. Biochem. 72, 248254

2. Carmichael J., Mitchell J. B., Friedman N., GazDar A. F. and Russo A. (1988) Glutathione and related enzyme activity in human lung cancer cell lines. Brit. J. Cancer 58, 437-440

3. Chasseaud L. F. (1979) The role of glutathione and glutathione S-transferases in the metabolism of chemical carcinogens and other electrophilic agents. Adv. Cancer Res. 29, 175-274

4. DiERICKX P. J. (1987) Inhibition of glutathionedependent uridine uptake in cultured human hepatoma cells. Med. Sci. Res. 15, 1349-1350

5. Guthenberg C. and Mannervik B. (1981) Glutathione $S$-transferase (transferase $\pi$ ) from human placenta is identical or closely related to glutathione $S$-transferase (transferase $\varrho$ ) from 
erythrocytes. Biochim. Biophys. Acta 661, 255260

6. Habig W. H., Pabst M. J. and Jakoby W. B. (1974) Glutathione S-transferases. The first enzymatic step in mercapturic acid formation. J. Biol. Chem. 249, 7130-7139

7. Ito N., Tsuda H., Tatematsu M., Inoue T., Tagawa Y., Aoki T., Uwagawa S., Kagawa M. Ogiso T., Masui T., Imaida K., Fukushima S. and Assmoto M. (1988) Enhancing effect of various hepatocarcinogens on induction of preneoplastic glutathione S-transferase placental form positive foci in rats-an approach for a new medium-term bioassay system. Carcinogenesis 9, 387-394

8. Kano T., SaKai M. and Muramatsu M. (1987) Structure and expression of a human class $\pi$ glutathione $S$-transferase messenger RNA. Cancer Res, 47, 5626-5630

9. Ketrerer B., Coles B. and Meyer D. J. (1983) The role of glutathione in detoxication. Environ. Health Persp. 49, 59-69

10. Knowles B. B., Howe C. C. and Aden D. P. (1980) Human hepatocellular carcinoma cell lines secrete the major plasma proteins and hepatitis B surface antigen. Science 209, 497499

11. Laemmli U. K. (1970) Cleavage of structural proteins during the assembly of the head of bacteriophage T4. Nature 227, 680-685

12. Limbosch S. (1983) Benzo[a]pyrene- and aldrinmetabolizing activities in cultured human and rat hepatoma cell lines. J. Nat. Cancer Inst. 71, 281-286

13. Macnab G. M., Alexander J. J., Lecatsas G., Bey E. M. and Urbanowicz J. M. (1976) Hepatitis B surface antigen produced by a human hepatoma cell line. Brit. J. Cancer 34, 509-515

14. Mannervik B. and Danielson U. H. (1988) Glutathione transferases-Structure and catalytic activity. CRC Crit. Rev. Biochem. 23, 283337

15. Marcus C. J., HablG W. H. and Jakoby W. B. (1978) Glutathione transferase from human erythrocytes. Nonidentity with the enzymes from liver. Arch. Biochem. Biophys. 188, 287-293

16. Sato K. (1988) Glutathione $S$-transferases and hepatocarcinogenesis. Jap. J. Cancer Res. 79, 556-572

17. Shea T. C., Kelley S. L. and Henner W. D. (1988) Identification of an anionic form of glutathione transferase present in many human tumors and human tumor cell lines. Cancer Res. 48, 527-533

18. Simons P. C. and VAnder JAGT D. L. (1977) Purification of glutathione $S$-transferases from human liver by glutathione-affinity chromatography. Anal. Biochem. 82, 334-341

19. Sмith G. J. and Litwack G. (1980) Roles of ligandin and the glutathione S-transferases in binding steroid metabolites, carcinogens and other compounds. Rev. Biochem. Toxicol. 2, 147

20. Soma Y., SAtoh K. and Sato K. (1986) Purification and subunit-structural and immunological characterization of five glutathione $S$-transferases in human liver, and the acidic form as a hepatic tumor marker. Biochim. Biophys. Acta 869, 247-258

21. Tahir M. K., Guthenberg C. and Mannervik B. (1985) Inhibitors for distinction of three types of human glutathione transferase. FEBS Lett. 181, 249-252

22. TAN K. H., Meyer D. J., Belin J. and Ketterer B. (1984) Inhibition of microsomal lipid peroxidation by glutathione and glutathione transferases $\mathrm{B}$ and AA. Role of endogenous phospholipase $\mathrm{A}_{2}$. Biochem. J. 220, 243-252

23. Trakshel G. M. and Maines M. D. (1988) Characterization of glutathione $S$-transferases in rat kidney. Alteration of composition by cisplatinum. Biochem. J. 252, 127-136

24. Vander JaGt D. L., Hunsaker L. A., Garcia K. B. and Royer R. E. (1985) Isolation and characterization of the multiple glutathione $S$ transferases from human liver. Evidence for unique heme-binding sites. J. Biol. Chem. 260, $11603-11610$ 